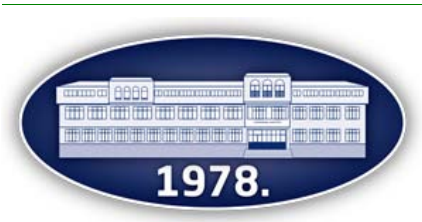

Publisher: Faculty of Agronomy Čačak

\title{
Determinant factors influencing organic foods purchase
}

\author{
Milica Čolović*, Vladimir Mitić \\ Faculty of Business, Singidunum University, Danijelova 32, 11000 Beograd \\ *Corresponding author: mcolovic@singidunum.ac.rs
}

Received 25 November 2020; Accepted 9 July 2021

\begin{abstract}
A B S T R A C T
The situation with the virus Covide-19 worldwide, in addition to the many questions of how to best protect ourselves, drew the attention of people and professional community, to the significance and the importance that a healthy nutrition has in preserving and building up immunity, and thus also in the prevention and protect the organism from various negative agents. Due to increased consumer concern for their own health and the environment the organic food market is one of the fastest growing markets in the food industry. The main goal of the current research is to examine determinant factors influencing organic foods purchase in our region. The sample consisted of 571 subjects from Serbia and the region. The data were processed by the SPSS program, and the obtained results show that in our country, as well as anywhere in the world, the price is the most common barrier in the situation of buying organic food. Gender of our subjects was not a significant factor in making the decision and realization of the purchase, while their marital status and age had an influence in making the mentioned decision. In general, our research showed that younger respondents, who are not married, are the most common buyers of organic food.
\end{abstract}

Keywords: organic food, factors in making a decision of foods purchase, gender, marital status, age, country.

\section{И 3 В О Д}

Ситуација са Вирусом Ковид-19 у целом свету, поред многобројних питања о томе како се најбоље заштити, скренула је пажњу људи, али и стручне јавности, на значај и важност коју здрава исхрана има у очувању и изграђивању имунитета, а самим тим и у превенцији и заштити организма од различитих негативних агенаса, који су у зимском периоду нарочито активни. Тржиште органске хране је једно од најбрже растућих тржишта у прехрамбеној индустрији услед повећане бриге потрошача за сопствено здравље и животну средину. Предмет актуелног истраживања представља испитивање главних фактора приликом доношења одлуке о куповини органске хране код људи из нашег региона. У ту сврху конструисан је посебан инструмент којим се регистровала учесталост и интензитет појединих фактора, који су се, претрагом светске и домаће литературе, у резултатима истраживања показали најзаступљенијим. Узорак је чинио 571 испитаник из Србије и региона. Подаци су обрађени СПСС програмом, а добијени резултати показују да је и код нас, као и свуда у свету цена најчешћа баријера приликом куповине органске хране. Пол није био значајан фактор приликом доношења одлуке и реализације куповине, док су брачни статус, односно узраст испитаника, имали утицаја у доношењу поменуте одлуке. Генерално гледано, у нашем истраживању се показало да су млађи испитаници, који нису у браку најчешћи купци органске хране.

Кључне речи: органска храна, главни фактори при куповини, пол, брачни статус, узраст, земља.

\section{Introduction}

The situation with the virus Covide-19 worldwide, in addition to the many questions of how to best protect ourselves, drew the attention of people, and also the professional community, to the significance and the importance that a healthy nutrition has in preserving and building up immunity, and thus also in the prevention and protect the organism from various negative agents, which are especially active in the winter. The importance of proper nutrition, so far, has been mainly considered, only in situations where people have certain specific health problems, such as various types of food allergies or intolerances, diabetes, cardiovascular diseases or various diseases of the digestive tract, as well as specific problems in nutrition which are psychogenic character, such as anorexia, bulimia and obesity. Usually, when it comes to people of all ages, without any major health problems, the importance of healthy eating habits has not been of primary importance so far.

The organic food market is one of the fastest growing markets in the food industry, due to increased consumer concern for their own health and the environment. It is estimated that the organic food market will grow by $10-20 \%$ per year due to the growing demand for organic products (Zepeda, 2007). Therefore, it is not surprising that in the period from 2013 to 2015, the market value of this industry quadrupled (Froehlich et al., 2018). The value of the organic food market in 2014 was around 80 billion dollars, with the leading countries being the USA, Germany, France and China (Golijanin and Popović 2018). The largest market for organic food is North America and is estimated at 51 billion US dollars, while 
Europe is in second place with 45 billion US dollars (IFOAM, 2020).

In Serbia, the organic food market is not sufficiently developed due to poor consumer information and undeveloped awareness of the benefits of organic food (Vlahović et al., 2011). In addition to insufficient information on the safety and quality of organic food, the low standard of living is a crutial factor and present major and an important obstacle (Golijan, 2016). Therefore, some authors (März et al., 2012) describe the organic food market in Serbia as small and very modest. However, some other authors believe that organic food will be increasingly bought by educated consumers and consumers who care about their health, and that organic food will become part of the daily diet and rutine, so its higher price will not be such an obstacle to them (Renko et al., 2011).

According to some authors (Marreiros et al., 2010) gender has no significant influence on a decision of purchasing organic food, as the approximate same number of consumers of organic food in Germany and Portugal are male and female. The Irianto (2015) disagrees with the previous authors, and he believes that gender influences the decision to purchase, precisly that women tend to buy more organic food than men. Also, research that included about 700 adolescents showed that females have more positive attitudes towards organic food than males (Stobbelaar et al., 2006). In accordance to this results are ones obtained in a study of 340 Viennese high school students, where girls were more willing to buy and consume organic products than boys (Gotschi et al., 2010).

Some other studies have also confirmed that a higher percentage of women have positive attitudes toward organic food compared to men $\left(\mathrm{O}^{\prime}\right.$ Donovan and McCarthy, 2002; McEachern and McClean, 2002; Đokić et al., 2014; Vitters $\varnothing$ and Tangeland, 2015; Petrescu et al., 2016; Kranjac et al., 2017).

The results of research conducted by researchers in the United States showed that marital status has an impact when it comes to purchasing food, and that married people are main buyers of organic products (Dimitri and Dettmann 2012). Similar results were obtained in Canada, where typical buyers of organic products are most often married and have one child (Hamzaoui-Essoussi and Zahaf, 2012).

Some authors have found correlation between the age of consumers and the purchase of organic food. Thus, some authors state that regular consumers of organic food in the UK are older than the average population $-58 \%$ of their respondents were over 56 years old (Geen and Firth, 2006). Also, the consumers of organic fruit are most often betwen 45 and 54 years (Mintel, 2000). Also, research in Bangkok, showed that the local consumers of organic food tend to be older than the other consumer groups (Schobesberger et al., 2008). The opposite results were obtained by the authors in the UK, who state that older consumers are less likely to buy organic products compared to younger consumers (Rimal et al., 2005), as well as the consumers in the US (Durham and Andrade, 2005). However, many authors argue that age has no effect on consumers when it comes to making a decision to purchase organic food (Hassan et al., 2009; Hughner et al., 2011) or has minimal impact on the food purchase (Lea and Worsley, 2005).

\subsection{Main factors influencing organic foods purchase}

There are certain obstacles and barriers that affect the consumers to give up or to much lesser extent of buying organic products. The most common obstacles that appear, according to the results of many researches, are: high price of organic products, distrust in the certification process, unavailability or scarce offer, non-recognition of organic products, different taste, bad design and others.

\subsubsection{Price}

The higher price of organic products compared to conventional products is an important factor in decision and often a major barrier to purchase because customers feel they are not getting adequate benefits and advantages by purchasing organic products. Such is the situation in Cairo (Mohamed et al., 2012) and Sweden (Kihlberg et al., 2007). Although Swedish consumers think that organic food is tastier than conventional, $50 \%$ of them stated that they will not buy an organic product that is significantly more expensive than the conventional one. The higher price of organic products compared to conventional products is the most common reason why consumers do not buy organic products and this has been confirmed by a large number of studies (Ureña et al., 2007; Brown et al., 2009; Gottschalk and Leistner, 2013; Vitters $\emptyset$ and Tangeland, 2015; Van Doorn and Verhoef, 2015; Petrescu et al., 2016).

On the other hand, research shows that consumers are willing to pay a higher price for organic products compared to conventional one, if they meet certain conditions. For example, consumers are willing to pay $5-50 \%$ higher price because they see that cost as an investment in their health (Chandrashekar, 2014). One research conducted in Serbia showed that a surprisingly significant part of consumers are willing to pay a higher price for organic products compared to conventional ones (Golijan and Dimitrijević, 2018).

\subsubsection{Taste}

Consumers who traditionally consume conventional food are accustomed to its taste and smell, so it is difficult for them to make a big change and decide to buy and consume organic food. Satisfaction with the taste of conventional food with a lack of knowledge is an important factor and barrier for large part of consumers to switch to conventional food (Botonaki et al., 2008).

\subsubsection{Certification}

In each country there are appropriate institutions that check the origin and quality of organic products and issue certificates. Although their function is to increase customer confidence in the quality of organic products, customers often doubt the procedures by which certificates are obtained. This was confirmed by results of one research conducted in Italy, where it shown that customers not only do not believe in the quality of organic products and production processes of organic producers, but even doubt the institutions that deal with certification (O'Doherty Jensen et al., 2011). Distrust in the certification process and consumers in 
the Czech Republic is one of the main obstacles to the purchase of organic products with a lack of information and shorter shelf life of organic products (Zvěřinová et al., 2011). In general, poor knowledge and lack of trust in organic certification is one of the important factors and common barriers to purchasing organic products (Hughner et al., 2007; Krystallis et al., 2008).

\subsubsection{Disinterest and uninformedness}

Lack of information and disinterest of consumers are also one of the main factors and frequent obstacles that make them give up buying organic products. This is confirmed by a number of studies (McEachern and McClean, 2002; Ham et al., 2016; Brył, 2018).

\subsubsection{Poor packaging design and non-recognition of organic food}

One of the common problems that consumers face is that they do not know how to distinguish organic from conventional food. This is a major problem for about $21 \%$ of consumers in Poland according to a survey conducted by Żakowska-Biemans (2011). Poor design and the inability to distinguish organic from inorganic products with poor information are the main barriers for Slovak consumers to buy organic products (Predanocyová et al., 2018), as well as for Polish consumers (Wojciechowska-Solis and Soroka, 2017).

\subsubsection{Unavailability and scarce supply}

Organic food stores are sometimes remote for consumers or there is a scarce supply of organic products in stores, which negatively affects their purchase. The unavailability of organic food products, along with high prices, are important factors which present a major barrier to the purchase of organic products according to research conducted in Belgium (Aertsens et al., 2011), Australia (Batt and Giblett, 1999), as well as in Ireland (O'Donovan and McCarthy, 2002). The same barriers are faced by American (Li et al., 2007) and Chinese consumers (Thøgersen and Zhou, 2012). Scarce supply and poor diversity are also one of the biggest barriers for consumers in Costa Rica (González, 2009).

\subsubsection{Subjective norms}

Last, but certainly not less important factors in a situation of purchasing organic foods, are those psychological types, which can be subsumed under a subjective norms. Egoism is one of the reasons why Dutch consumers do not buy organic products according to research (Van Doorn and Verhoef, 2015). Skepticism about the benefits of consuming organic food is one of the barriers for German consumers (Meyer-Höfer et al., 2015). Also, Norwegian consumers who, for completely personal reasons, do not notice the benefits of consuming organic food, often give up from buying it (Vitters $\varnothing$ and Tangeland, 2015).

\section{Materials and methods}

The main goal of this research is to identify the basic and determinant factors that influence organic foods purchase. After that, the obtained results are checked through specific goals in relation to the control variables: gender, marital status, age of the respondents and country in which they live. The basic hypothesis, with which we started the research, was that people have different reasons when they have to make and realize decision to purchase organic food (X1). In accordance with the objectives from which they originated the potential differences between respondents of different gender (X2), marital status (X3) age (X4) and country (X5) are specified. To collect data, a special questionnaire was constructed which, in addition to basic demographic characteristics, registered the presence and intensity of main factors in decision that may occur when it comes to purchase organic food: poor information and lack of interest of respondents in organic food, high price, (bad) taste, unavailability, distrust in the certification and composition of the product imprinted on the label, poor packaging design, the belief that organic food is intended for "snobs" as well as the poor supply of organic products on the domestic market. Besides basic descriptive statistical measures, differences between groups of respondents were examined, when it comes to gender, marital status and age. Data were processed by the SPSS program (version 26) which is often first choise of Statistical Package applied in the Social Sciences. The t-test was used to determine the differences in scores by gender, while the KruskalWallis test was used to determine the differences between a larger number of groups of respondents, when the main factors in purchasing organic food were observed in relation to the marital status, age and country in which they live. The sample consisted of 571 respondents, 122 (21.4\%) were males and 449 (78.6\%) were females. Respondents were divided into 4 age groups: 18-24 years - 108 respondents (18.9\%), 25-39 years - $276(48.3 \%), 40$ - 64 years $183(32 \%)$ and over 65 years we have only 4 respondents $(0.7 \%)$. They had different marital status: 149 (26.1\%) stated that they were single, $122(21.4 \%)$ were in relationship, the most of them were married - $255(44.7 \%)$, while only 35 $(6.1 \%)$ were divorced or widows - $10(1.8 \%)$. Most of them was from Serbia - 485 (84.9\%), Macedonia - 45 (7.9\%), Bosnia and Herzegovina - 14 (2.5\%), Serbian Republic - 11 (1.9\%), Croatia - 10 (1.8\%) and Montenegro - 6 (1.1\%).

\section{Results and discussions}

The main factor and the biggest obstacle and barrier to the purchase of organic food in our sample is the high price. Even $38.53 \%$ of our respondents stated this as the main reason. Distrust in certification and unavailability of organic products on our market are in second $(16.46 \%)$ and third $(16.11 \%)$ place. It is followed by disinterest and lack of information of people (12.78\%), poor supply of organic products $(10.68 \%)$, taste $(4.38 \%)$, while certain subjective norms $(0.70 \%)$ and poor product design $(0.35 \%)$ are negligibly present among the main reasons and obstacles for the purchase of organic food (Table 1). 
Table 1.

Descriptive statistics for the determinant factors in purchasing of organic food

\begin{tabular}{lll}
\hline Value label & Frequency & Percent \\
\hline Disinterest and & 73 & 12.78 \\
uninformedness & 220 & 38.53 \\
High Price & 25 & 4.38 \\
Taste & 92 & 16.11 \\
Unavailability and scarce & 94 & 16.46 \\
supply & 2 & 0.35 \\
Distrust of certification & 4 & 0.70 \\
Poor design & 61 & 10.68 \\
Subjective norms & 571 & 100 \\
Scarce supply & & \\
\hline Total &
\end{tabular}

The obtained results confirm our general hypothesis (X1), which is in accordance with the data obtained in most of the mentioned studies. As we see, high price is the very important factor and presents the main obstacles to purchase organic food that appeared in a lot of studies (Ureña et al., 2007; Brown et al., 2009; Gottschalk and Leistner, 2013; Vitterso and Tangeland, 2015; Van Doorn and Verhoef, 2015; Petrescu et al., 2016). Distrust of certification, which is the second most important factor and obstacle in our research, has been also confirmed by previous researches (Hughner et al., 2007; Krystallis et al., 2008; O'Doherty Jensen et al., 2011; Zverinova et al., 2011). Immediately after distrust of certification, respondents from our study stated unavailability as a barrier to purchasing organic food (Batt and Giblett, 1999; O’Donovan and McCarthy, 2002; Aertsens et al., 2011; Thøgersen and Zhou, 2012). Although some researchers emphasized disinterest, lack of information (McEachern and McClean, 2002; Ham et al., 2016; Brył, 2018) and scarce supply of organic products as important barriers (González, 2009), in our study they were not so significant factors. Also, different taste, subjective norms and poor design of organic products have hardly proved to be significant factors in a situation when it is necessary to make a decision whether to buy organic food.

The following table shows the obtained differences in arithmetic means between men and women on the variable determinant factors to the purchase of organic food.

Table 2.

Gender differences in arithmetic means

\begin{tabular}{ccccc}
\hline & Gender & $\mathrm{N}$ & $\mathrm{AS}$ & $\mathrm{SD}$ \\
\hline $\begin{array}{c}\text { DETERMINANT } \\
\text { FACTORS } \\
\begin{array}{c}\text { IN PURCHASING } \\
\text { OF ORGANIC } \\
\text { FOOD }\end{array}\end{array}$ & Male & 122 & 3.42 & 2.23 \\
\cline { 2 - 5 } & Female & 449 & 3.42 & 2.05 \\
\hline
\end{tabular}

As can be assumed, based on identical values of arithmetic means, which was confirmed by t-test results, in our sample there are not statistically significant differences in scores between male and female respondents, when it comes to determinant factors to the purchase of organic food $(\mathrm{t}=-0.02 ; P>$ 0.05) (Table 3).
Table 3.

Results of t-test and statistical significance of obtained gender differences

\begin{tabular}{cccc}
\hline DETERMINANT & $\mathrm{t}$ & $\mathrm{df}$ & Sig. \\
\cline { 2 - 4 } FACTORS & -0.02 & 569 & 0.981 \\
IN PURCHASING OF & & & \\
ORGANIC FOOD & & & \\
\hline
\end{tabular}

The second hypothesis (X2) from which we started, that there are gender differences between respondents when it comes to determinant factors that occur in a situation of buying organic food, has not been confirmed in the current research. The obtained result is in accordance with the researches conducted in Germany and Portugal, but it is in contradiction with the results of some group of researchers (Đokić et al., 2014; Vitters $\varnothing$ and Tangeland, 2015; Petrescu et al., 2016; Kranjac et al., 2017). It should also be taken into account fact that, in some studies, the sample consisted of adolescents and high school students, who have not yet fully formed appropriate gender roles, so the obtained gender differences should be taken with caution.

However, when it comes to the variable marital status, obtained differences in the scores of the respondents were at a statistically significant level, when it comes to the main factors in making a decision of buying organic food (X2 $=14.10 ; P<0.05)$ (Table 4$)$.

Table 4.

Kruskal - Wallis test results

\begin{tabular}{cc}
\hline & DETERMINANT FACTORS \\
& IN PURCHASING OF ORGANIC FOOD \\
\hline$X^{2}$ & 14.10 \\
$\mathrm{df}$ & 4 \\
Sig. & 0.007 \\
\hline Group variable: marital status
\end{tabular}

If we look more closely at the obtained differences in ranks, we could see that the main reason against and the biggest obstacles to the purchase of organic food have widows ( $M R=382.15)$. After them, high barriers have married people (MR $=305.25)$, followed by those who are divorced ( $M R=304.93)$. By far, the lowest scores on the examined variable are shown by persons who are in a relationship (MR $=260.83$ ), while only slightly higher scores have those who stated that do not have a partner $(\mathrm{MR}=262.78)$ (Table 5).

Table 5.

Differences in scores depending on the marital status of respondents

DETERMINANT FACTORS

IN PURCHASING OF ORGANIC FOOD

\begin{tabular}{lll}
\hline Marital status & N & Mean Rank \\
\hline Single & 149 & 262.78 \\
In a relationship & 122 & 260.83 \\
Married & 255 & 305.25 \\
Divorced & 35 & 304.93 \\
Widow & 10 & 382.15 \\
Total & 571 & \\
\hline
\end{tabular}

This confirmed our 3 hypothesis (X3), that marital status is an important factors that plays a role in the decision and realization of the purchase of organic food, which is in line with research conducted in many 
countries, with the difference that in America and Canada marriage was a facilitating factor in buying organic food, while in our research it proved to be a major obstacle.

As it was emphasized, the least barriers in buying organic food have people without partners, and those who are in a relationship. This can be explained by the fact that, above all, younger people are focused on a healthy lifestyle, positive habits, which include a healthy and better nutrition, as there are ongoing with modern trends and take better care of their physical appearance.

This result suggests that perhaps the age of the respondents actually plays a large role in the purchase of organic food, which proved to be correct. The obtained differences in the scores of the subjects measured by the Kruskal - Wallis test were at a statistically significant level $\left(X^{2}=9.11 ; P<0.05\right)$ (Table $6)$.

Table 6.

Kruskal - Wallis test results

\begin{tabular}{cc}
\hline & DETERMINANT FACTORS \\
& IN PURCHASING OF ORGANIC FOOD \\
\hline$X^{2}$ & 9.11 \\
$\mathrm{df}$ & 3 \\
Sig. & 0.028 \\
\hline
\end{tabular}

Group variable: age of respondents

The main factors, in the form of a highest obstacles in buying organic food, are the most pronounced in middle-aged respondents (MR=304.93), followed by those older than $65(\mathrm{MR}=297.25)$, then those between 25 and 39 years (MR=288.90), while convincingly the lowest scores are shown by the youngest respondents, aged 18 up to 24 years (MR=246.85), which means that they are the group that most often buy organic food (Table 7).

Table 7.

Differences in scores depending on the age of respondents

\section{DETERMINANT FACTORS}

IN PURCHASING OF ORGANIC FOOD

\begin{tabular}{lll}
\hline Age & N & Mean Rank \\
\hline 18 to 24 years & 108 & 246.85 \\
25 to 39 years & 276 & 288.90 \\
40 to 64 years & 183 & 304.48 \\
Over 65 years & 4 & 297,25 \\
\hline Total & 571 & \\
\hline
\end{tabular}

The obtained results also support our forth hypothesis (X4), that the age of the respondents plays an important role in buying organic food. In contrast to research conducted in Bangkok and the United Kingdom, but in line with other group of research (Durham and Andrade, 2005; Rimal et al., 2005), younger respondents are, as we assumed based on the results obtained by testing the previous hypothesis, more frequent buyers of organic food.

Our last hypothesis which regards to the existence of differences in determinant factors in purchasing of organic food between respondents who live in different countries of our region (Serbia, Macedonia, Bosnia and Herzegovina, Serbian Republic, Croatia and Monte Negro), has not been confirmed $\left(X^{2}=3.906 ; P>0.05\right)$ (Table 8).
Table 8.

Kruskal - Wallis test results

\begin{tabular}{cc}
\hline & DETERMINANT FACTORS \\
& IN PURCHASING OF ORGANIC FOOD \\
\hline$X^{2}$ & 3.906 \\
$\mathrm{df}$ & 5 \\
sig. & 0.563 \\
\hline \multicolumn{2}{l}{ Group variable: countries from our region }
\end{tabular}

The obtained differences in scores between respondents from different countries of our region, which are an integral part of the presentation of Kruskal - Wallis test results, are shown in Table 9.

The reason for that may be the uneven number of respondents from these countries, and the predominance of respondents from Serbia. On the other hand, we must not overlook the fact that all the peoples of these countries were part of one great state and that there is probably still something of a common mentality left.

Certainly, future research should be interesting to organize with a more uniform sample and focus on discovering possible differences in other important factors in purchasing organic food, but also at food preferences, which occur among members of different nations from our region.

Table 9.

Differences in scores depending on the age of respondents

\begin{tabular}{lll}
\hline \multicolumn{3}{c}{ DETERMINANT FACTORS } \\
\multicolumn{3}{c}{ IN PURCHASING OF ORGANIC FOOD } \\
\hline Country & $\mathrm{N}$ & Mean Rank \\
\hline Serbia & 485 & 283.48 \\
Croatia & 10 & 241.75 \\
Macedonia & 45 & 325.01 \\
Bosnia and Herzegovina & 14 & 278.64 \\
Montenegro & 6 & 259.33 \\
Serbian Republic & 11 & 301.86 \\
\hline Total & 571 & \\
\hline
\end{tabular}

\section{Conclusions}

Current research has shown that people generally have very different reasons when they need to make decision whether to buy organic food. Some of them were common for people living in our region and in different countries and other continents, while some were completely different. Probably cultural factors play a big role, as well as the current socio-economic situation, living standard and level of development of these countries. Price has generally, in most research as well in ours, proven to be a major barrier to buying organic food. On the other hand, in second place among the determinant factors, in our sample, there is a lack of confidence in the certification and the unavailability of organic products in our market, which is not one of the main obstacles related to the purchase of organic food in developed countries. Scarce supply, lack of interest, uninformedness and different taste are weak obstacles in our population, while poor design and subjective norms have almost no influence in a situation when is need to make a decision whether or not to buy organic food. Also, gender as well as country in our region where respondents live, did not prove to be a significant factors in our sample, while marital status 
and age of the respondents played important roles. In general, we can conclude that younger respondents, who are not married, are the most frequent buyers of organic food.

\section{Acknowledgment}

This work has been supported by the Singidunum University, Faculty of Business in Belgrade.

\section{Declaration of competing interest}

There is not any personal and/or financial relationships with other people or organizations that could inappropriately influence (bias, non-compliance with the academic code) their work.

\section{References}

Aertsens, J., Mondelaers, K., Verbeke, W., Buysse, J., Van Huylenbroeck, G. (2011). The influence of subjective and objective knowledge on attitude, motivations and consumption of organic food. British Food Journal, 113(11), 1353-1378.

Batt, P. J., Giblett , M. (1999). A pilot study of consumer attitudes to organic fresh fruit and vegetables in Western Australia. Food Australia, 51(11), 549-555.

Botonaki, A., Polymeros, K., Tsakiridou, E., Mattas, K. (2006) The role of food quality certification on consumers' food choices. British Food Journal, 108(2), 77-90.

Brown, E., Dury, S., Holdsworth, M. (2009). Motivations of consumers that use local, organic fruit and vegetable box schemes in Central England and Southern France. Appetite, 183-188.

Bryła, P. (2016). Organic food consumption in Poland: Motives and barriers. Appetite, 105, 737-746.

Chandrashekar, H. (2014). Consumers Perception towards Organic Products. International Journal of Research in Business Studies and Management, 1(1), 52-67.

Dimitri, C., Dettmann, R. L. (2012). Organic food consumers what do we really know about them? British Food Journal, 114(8), 1157-1183.

Đokić, I., Đokić, N., Pavlović, N., Kovac, R. (2014). Promotion of organic food in Serbia: Implications from organic food consumers' profile research. Ekonomika poljoprivrede, 61(4), 837-849.

Durham, C., Andrade, D. (2005). Health vs. Environmental Motivation in Organic Preferences and Purchases. American Agricultural Economics Association Annual Meeting. Providence, 1-21.

Froehlich, A. G., Melo, A. S., Sampaio, B. (2018). Comparing the Profitability of Organic and Conventional Production in Family Farming: Empirical Evidence From Brazil. Ecological Economics, 150, 307-314.

Geen, N., Firth, C. (2006). The committed organic consumer. Joint Organic Congress. Odense, 1-2.

Golijan, J. (2016). Motivi koji utiču na kupovinu organskih prehrambenih proizvoda. Agroekonomika, 45, 73-80.

Golijan, J., Dimitrijević, B. (2018). Global organic food market. Acta Agriculturae Serbica, 23(46), 125-140.

Golijanin, J., Popović, A. (2018). Basic characteristics of the organic agriculture market C. Proceedings of the Fifth International Conference Competitiveness Of Agro-Food And Environmental Economy. Bucharest, 236-244.

González, J. (2009). Market trends and consumer profile at the organic farmers market in Costa Rica. British Food Journal, 111(5), 498-510.

Gotschi, E., Vogel, S., Lindenthal, T., Larcher, M. (2010). The Role of Knowledge, Social Norms, and Attitudes Toward Organic Products and Shopping Behavior. The Journal of Environmental Education, 41(2), 88-100.

Gottschalk, I., Leistner, T. (2013). Consumer Reactions to the Availability of Organic Food. International Journal of Consumer Studies, 37(2), 136-142.
Ham, M., Pap, A., Bilandzic, K. (2016). Percieved barriers for buying organic food products. 18th International Scientific Conference on Economic and Social Development - "Building Resilient Society". Zagreb, Croatia, 162-174.

Hamzaoui-Essoussi, L., Zahaf, M. (2012). Canadian Organic Food Consumers' Profile and Their Willingness to Pay Premium Prices. Journal of International Food \& Agribusiness Marketing, 24(1), 1-21.

Hassan, D., Monier, S., Nichele, V., Simioni, M. (2009). Organic Food Consumption Patterns in France. Journal of Agricultural \& Food Industrial Organization, 1-23.

Hughner, R. S., Prothero, A., Shultz , C. J., McDonagh, P. (2007). Who Are Organic Food Consumers? Journal of Consumer Behaviour, 62(2-3), 94-110.

IFOAM. (2020). The World of Organic Agriculture STATISTICS \& EMERGING TRENDS 2020

Irianto, H. (2015). Consumers' Attitude and Intention Towards Organic Food Purchase: An Extension of Theory of Planned Behavior in Gender Perspective. International Journal of Management, Economics and Social Sciences, 4(1), 17-31.

Kihlberg, I., Risvik, E. (2007). Consumers of organic foods value segments and liking of bread. Food Quality and Preference, 18(3), 471-481.

Kranjac, M., Vapa-Tankosić, J., Knezevic, M. (2017). Profile of organic food consumers. Ekonomika poljoprivrede, 64(2), 497-514

Krystallis, A., Vassallo, M., Chryssochoidis, G. M., Perrea, T. (2008). Societal and individualistic drivers as predictors of organic purchasing revealed through a portrait value questionnaire (PVQ)-based inventory. Journal of Consumer Behaviour, 7(2), 164-187.

Lea, E., Worsley, T. (2005). Australians' organic food beliefs, demographics and values. British Food Journal, 107(11), 855-869.

Li, J., Zepeda, L., Gould, B. W. (2007). The demand for organic food in the U.S.: An empirical assessment. Journal of Food Distribution Research, 38, 54-69.

Marreiros, C., Lucas, M. , Röhrich, K. (2010). Explaining organic food choice on the basis of socio-demographics. A study in Portugal and Germany. CEFAGE-UE Working, 1-18.

März, U., Stolz, T., Kalentić, M., Stefanović, E. (2012). Organic agriculture in Serbia 2012-At a Glance, 1-44.

McEachern, M. G., McClean, P. (2002). Organic purchasing motivations and attitudes: Are they ethical? International Journal of Consumer Studies, 26(2), 85-92.

Mintel. (2000). Organic Food and Drink Retailing, Market Intelligence Unit of the UK Economist. London.

Mohamed, M., Chymis, A. G., Shelaby, A. (2012). Determinants of Organic Food Consumption in Egypt. International Journal of Economics and Business Modeling, 3(3), 183191.

O’Doherty Jensen, K., Denver, S., Zanoli, R. (2011). Actual and potential development of consumer demand on the organic food market in Europe. NJAS - Wageningen Journal of Life Sciences, 58(3-4), 79-84.

O'Donovan, P., McCarthy, M. (2002). Irish consumer preference for organic meat. British Food Journal, 104, 353-370.

Petrescu, D. C., Petrescu-Mag, R. M., Azadi, H., Burny, P. (2016). A new wave in Romania: organic food. Consumers' motivations, perceptions, and habits. Agroecology and Sustainable Food Systems, 41(1), 46-75.

Predanocyová , K., Šedík, P., Kubicová, L., Horská, E. (2018). Consumption and offer of organic food on the Slovak market. Acta universitatis agriculturae et silviculturae mendelinae brunensis, 66 (5), 1315-1323.

Renko, N., Butigan, R., Renko, S., \& et al. (2011). WP7 Market data, market trends and consumer behaviour report. Theme 2 - Food, Agriculture and Fisheries, and Biotechnology Activity 2 Fork to farm FP7 KBBE 2007 2.1-02

Rimal, A. P., Moon, W., Balasubramanian, S.,. (2005). Agro-biotechnology and organic food purchase in the United Kingdom. British Food Journal, 107(2), 84-97. 
Schobesberger, B., Darnhofer, I., Somsook, S., Vogl, C.R. (2008). Consumer perceptions of organic foods in Bangkok, Thailand. Food Policy, 33(2), 112-121.

Stobbelaar, D. J., Casimir, G., Borghuis, J., Marks, I., Meijer, L., Zebeda, S. (2006). Adolescents' attitudes towards organic food: a survey of 15- to 16-year old school children International Journal of Consumer Studies, 31(4), 349-356.

Thøgersen, J., Zhou, Y. (2012). Chinese consumers' adoption of a 'green' innovation - The case of organic food. Journal of Marketing Management, 28(3-4), 313-333.

Ureña, F., Bernabeu, R., Olmeda, M. (2007). Women, Men and Organic Food: Differences in Their Attitudes and Willingness to Pay. A Spanish Case Study. International Journal of Consumer Studies, 32(1), 18-26.

Van Doorn, J., Verhoef, P. C. (2015). Drivers of and Barriers to Organic Purchase Behavior. Journal of Retailing, 91(3), 436-450.

Vitters $\varnothing$, G., Tangeland, T. (2015). The role of consumers in transitions towards sustainable food consumption. Journal of Cleaner Production, 92, 91-99.
Vlahović, B., Radojević, V., Živanić, I.,. (2011). Istraživanje stavova potrošača o potrošnji organske hrane u Srbiji. Ekonomika poljoprivrede, 58(3), 443-456.

Meyer-Höfer, M., Olea-Jaik, E., Padilla-Bravo, C.A., Spiller, A. (2015). Mature and emerging organic markets: Modelling consumer attitude and behaviour with partial least square approach. Journal of Food Products Marketing, 21, 626-653.

Wojciechowska-Solis, J., Soroka, A. (2017). Motives and barriers of organic food demand among polish consumers: A profile of the purchasers. British Food Journal, 119, 2040-2048.

Żakowska-Biemans, S. (2011). Polish consumer food choices and beliefs about organic food. British Food Journal, 113(1), 122-137.

Zepeda, L., Li, J. (2007). Characteristics of Organic Food Shoppers. Journal of Agricultural and Applied Economics, 39(1), 17-28.

Zvěřinová, I., Urban, J., Ščasný, M. (2011). Why do Czech consumers purchase organic food. Business, 3, 20-28. 
